\title{
Variability of Aerosol Optical Depth over Cerrado of Mato Grosso, Brazil
}

\author{
Rafael da Silva Palácios", Fernando da Silva Sallo, José de Souza Nogueira \\ Institute of Physics, Federal University of Mato Grosso, Brazil
}

Copyright $\bigcirc 2016$ by authors, all rights reserved. Authors agree that this article remains permanently open access under the terms of the Creative Commons Attribution License 4.0 International License

\begin{abstract}
The optical properties of aerosols have an important meaning in atmospheric research issues. This work proposes a seasonal and inter-annual characterization of the Aerosol Optical Depth (AOD) at $500 \mathrm{~nm}$ through a transition region Pantanal, Cerrado (Cerrado characteristics) in the south central region of the State of Mato Grosso. AOD $500 \mathrm{~nm}$ data were acquired from the network AERONET 2001 to 2013. The daily values AOD $500 \mathrm{~nm}$ have a seasonal pattern, with minimum and maximum in the wet and dry seasons, respectively. The minimum values were mostly around to 0,02 in the wet season while the maximum values close to 5,23 in the dry season. Regarding the inter-annual characterization, it was found that is not a periodic behavior with large variations from year to year. The monthly averages of AOD 500nm were correlated with the monthly records of fire outbreaks in the State of Mato Grosso, however, there was no statistically significant correlation, which shows that this relationship exists, but it is not simple.
\end{abstract}

Keywords AERONET. Biomass Burning, Depression Cuiabana

\section{Introduction}

South Central region of Mato Grosso state is a strategic region for analysis of the optical profile of atmospheric aerosols from biomass burning, since this region is affect by numerous outbreaks of fires in the dry season every year [1]. The mid-west region of Brazil can contribute either to analysis of natural aerosols or anthropogenic aerosol analysis emitted by burning biomass [2], since this region is mainly composed of tropical savannas. In Brazil, savanna (locally known as cerrado) covers about $24 \%$ of the country and is the dominant vegetation in areas subjected to a prolonged dry season [3].

The Mato Grosso state contains three biomes, Amazon, Cerrado and Pantanal. Our study area lies in a transitional region between Pantanal and Cerrado[3]. The Brazilian Cerrado, in general, is responsible for large emissions of aerosols due to biomass burning. The extent of this biome covers approximately $2000 \mathrm{~km}^{2}$, of which approximately $50 \%$ of this territory is considering potentially arable land [4].

Due to pronounced dry season and thus natural and non-natural burning, the Cerrado becomes a potential emitter of particulate material into the atmosphere. The most AOD $550 \mathrm{~nm}$ critical period begins in July and is consistent from year to year. In general, this period can last just a few weeks, depending on the dry season severity that is related to $\mathrm{El}$ Niño Southern Oscillation (ENSO) [5, 14].

The AERONET (Aerosol Robotic Network) is an aerosol monitoring network, a terrestrial network of remote sensing distributed around the globe, among the various information provided by this network are the AOD values, these are provided for specific wavelengths among which is the 500 $\mathrm{nm}$ [6]. AOD $500 \mathrm{~nm}$ data for the Midwest region of Brazil has allowed a characterization of the optical properties of the local atmosphere, and it has aided for understanding the radiative exchanges in the range of visible light between the atmosphere and the surface [1]. The seasonal variability of AOD $500 \mathrm{~nm}$ values for the study area is closely relate to fire outbreaks records [1].

Thus, a quantification of this variable is needed to improve the understanding of the effects of aerosols on the radiative fluxes throughout the year. In this sense the objective of this study is to characterize a seasonal and inter-annual variability of AOD 500 $\mathrm{nm}$ in the Cerrado region in the state of Mato Grosso from data acquired from AERONET network for a time series extending from 2001 to 2013.

\section{Materials and Methods}

The study area is in a rural area (Miranda Farm), located approximately $20 \mathrm{~km}$ from the urban area of Cuiabá, capital of state of Mato Grosso (Figure 1) whose coordinates are $16^{\circ} \mathrm{S}$ and $56^{\circ} \mathrm{W}$ to $175 \mathrm{~m}$ altitude.

In the site is established the CIMEL photometer controlled by AERONET network. Full details of the instrumentation, measurement protocols, photometric accuracy, calibration, and processing methods can be found in the other work [6]. 


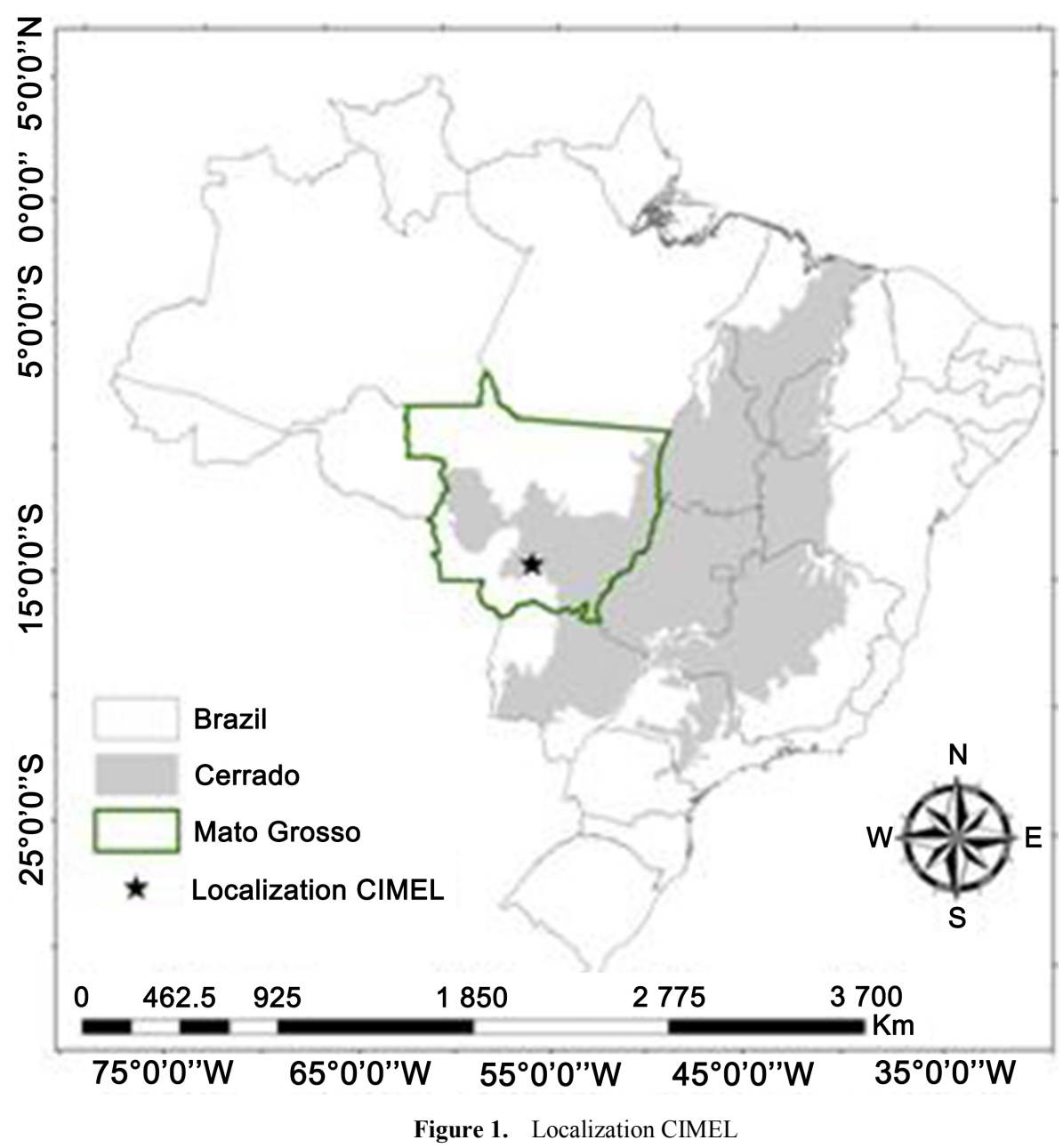

In this study we used the AOD $500 \mathrm{~nm}$ level 2.0 data, since the AERONET network data files are divided into three quality levels: level 1.0 for the raw data, level 1.5 for data without contamination of clouds and level 2.0 whose quality is certified by the AERONET [6,7]. The data used in this work can be accessed through the site http://www.inmet.gov.br/portal/index.php?r=bdmep/bdmep. From the National Institute for Space Research (INPE) [8], it were also used data referring to the number of fire outbreaks in Mato Grosso, which have a monthly resolution for the study period (2001-2013), this data is available in http://www.inpe.br/queimadas.

In the processing of data, it were analyzed maximum and minimum values as well as the means values for dry and wet seasons for each year and for the entire study period. Monthly averages were held for the entire data distribution, the values obtained in the monthly averages were also correlated with the fire outbreaks in the state of Mato Grosso for the same period. For determination of correlation was estimated Spearman correlation coefficient, since the distribution data corresponds to a non-linear and non-homogeneous distribution.

This study also used the model HYSPLIT trajectories
(Hybrid Single Particle Lagrangian Integrate Trajectoty Model), a model used to calculate trajectories and dispersion simulations and deposition of atmospheric particle [9]. The model can be run interactively via the web (http://ready.arl.noaa.gov/HYSPLIT.php). The web version has some limitations, to avoid saturation of the online system. However, there is an option model in the form of executable code available for MS Windows and MAC. This model was used to investigate possible external area that could contribute to increase AOD $500 \mathrm{~nm}$ over the study area (CIMEL coverage area).

\section{Results and Discussion}

The distribution of AOD $500 \mathrm{~nm}$ values shows clearly a seasonal pattern, the minimum values were recorded in the period from December to May for each year, while the maximum values were concentrated from July to November.

Figure (2a) represents the daily distribution of AOD 500 $\mathrm{nm}$ values, whereas Figure (2b) depicts the seasonal behavior of AOD $500 \mathrm{~nm}$ by overlapping the annual distributions of the values. 

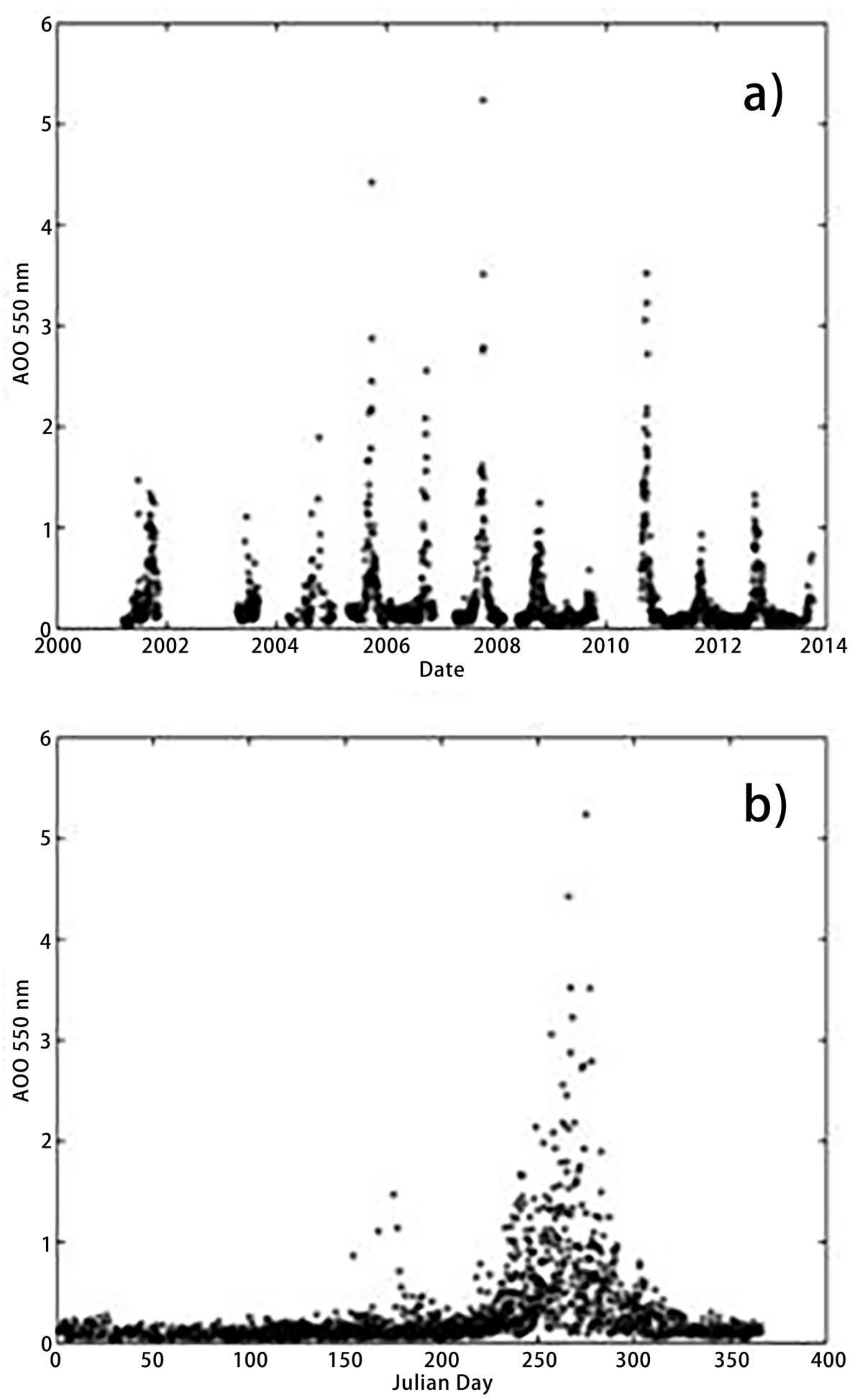

Figure 2. a) Daily Distribution of AOD $500 \mathrm{~nm}$ values from 2001 to 2013, b) distribution of AOD 500nm values over the day of the year. 
It can be seen from Figure (2a) a pretty long failure in 2002 due to technical problems in the photometer calibration. However the figures analyzed represent satisfactorily the maximum and minimum each year in the dry and wet seasons. For the year 2001 the daily peaks of AOD $500 \mathrm{~nm}$ reached 1,34 in the dry season, in 2003 the maximum record was 0,65 for the same period, in 2004 values exceeded 1,80 . All values are considered reliable data since the data acquired from the network AERONET were the level 2.0.

In 2005 and 2006 the maximum AOD $500 \mathrm{~nm}$ reached values greater than 4,00 and 2,50 respectively, while for 2007 the maximum value reached 5,23. For 2008 the maximum records occurred in the range of 1,24 to 0,58 , diminishing considerably in 2009. For the increasing time of AOD $500 \mathrm{~nm}$ values in 2009 there is another failure in the time series that continues until the increasing time in 2010, where the maximum peaks reach values close to 3,52 again. For 2011 and 2012 peak values were around 0,72 and 1,32, as well as for the year 2013.

Records of AOD $500 \mathrm{~nm}$ below 0,5 characterizes a virtually clean atmosphere, however [10] stated that under clean air conditions, the values may be less than 0,1 . The work of [1] for the years 2010, 2011 and 2012 reports values less than 0,5 for the our study area during the wet season in this region.

The average annuals as well as the standard deviations each year demonstrate the high variability of AOD in the dry season and low in the wet season. The annual variation showed the highest marks for the years 2005, 2006, 2007 and 2010 , these years present historical records of fires on Brazil. Table 1 shows the descriptive statistics for the variations of each season for each year and for the whole study period.

The monthly AOD $500 \mathrm{~nm}$ was related to the monthly records of outbreaks of fire for the state of Mato Grosso. Figure 3 shows the distribution of AOD $500 \mathrm{~nm}$ monthly values and records of outbreaks of fire.

One can see that the records of fires (Figure 3) are directly related to the increase in AOD $500 \mathrm{~nm}$ values, since the increase in fires events launches into the air a large amount of particulate matter, but records of large increases AOD values at $500 \mathrm{~nm}$ that are not accompanied by an increase in records of fires. For the years 2010 and 2011 the records of fires were approximately equal, as AOD $500 \mathrm{~nm}$ to 2010 figures peaked relatively higher than in 2011 .

The Spearman correlation coefficient for the relationship between AOD $500 \mathrm{~nm}$ and records of outbreaks of fire, was no statistically significant correlation $(0,02)$, which shows that other variables must be considered in the analysis of AOD $500 \mathrm{~nm}$ values. The work of [1] found a statistically significant correlation between these variables, however portrayed in his work series addresses a short break in the series.

Table 1. Descriptive statistics for the rainy and dry seasons for each year and throughout the study period

\begin{tabular}{|c|c|c|c|c|c|c|}
\hline \multicolumn{7}{|c|}{ AOD 500 nm } \\
\hline \multirow[b]{2}{*}{ Years } & \multicolumn{3}{|c|}{ Wet Season } & \multicolumn{3}{|c|}{ Dry Season } \\
\hline & Mean \pm SD & Minimum & Maximum & Mean \pm SD & Minimum & Maximum \\
\hline 2001 & $0,0616 \pm 0,0218$ & 0,0289 & 0,1218 & $0,5099 \pm 0,3481$ & 0,1065 & 1,3430 \\
\hline 2002 & -- & -- & -- & -- & -- & -- \\
\hline 2003 & $0,1743 \pm 0,0244$ & 0,1519 & 0,2365 & $0,2632 \pm 0,1160$ & 0,1193 & 0,6493 \\
\hline 2004 & $0,0925 \pm 0,0231$ & 0,0605 & 0,1245 & $0,4926 \pm 0,4225$ & 0,0725 & 1,8944 \\
\hline 2005 & $0,1954 \pm 0,0323$ & 0,1677 & 0,2309 & $0,8026 \pm 0,7154$ & 0,0843 & 4,4241 \\
\hline 2006 & $0,1350 \pm 0,0327$ & 0,0540 & 0,2142 & $0,5026 \pm 0,5404$ & 0,0728 & 2,5567 \\
\hline 2007 & $0,0991 \pm 0,0269$ & 0,0662 & 0,1626 & $0,9457 \pm 0,9275$ & 0,1373 & 5,2382 \\
\hline 2008 & $0,0992 \pm 0,0185$ & 0,0749 & 0,1306 & $0,4037 \pm 0,2515$ & 0,0943 & 1,2470 \\
\hline 2009 & $0,0999 \pm 0,0443$ & 0,0394 & 0,2600 & $0,1778 \pm 0,0952$ & 0,0719 & 0,5813 \\
\hline 2010 & -- & -- & -- & $0,9977 \pm 0,7622$ & 0,1650 & 3,5208 \\
\hline 2011 & $0,0695 \pm 0,0210$ & 0,0361 & 0,1146 & $0,2886 \pm 0,1775$ & 0,0636 & 0,9321 \\
\hline 2012 & $0,0831 \pm 0,0273$ & 0,0309 & 0,1582 & $0,4122 \pm 0,3111$ & 0,0734 & 1,3231 \\
\hline 2013 & $0,0921 \pm 0,0322$ & 0,0294 & 0,1592 & $0,2845 \pm 0,1789$ & 0,0809 & 0,7244 \\
\hline All years & $0,0965 \pm 0,0408$ & 0,0289 & 0,2600 & $0,5389 \pm 0,5607$ & 0,0636 & 5,2382 \\
\hline
\end{tabular}




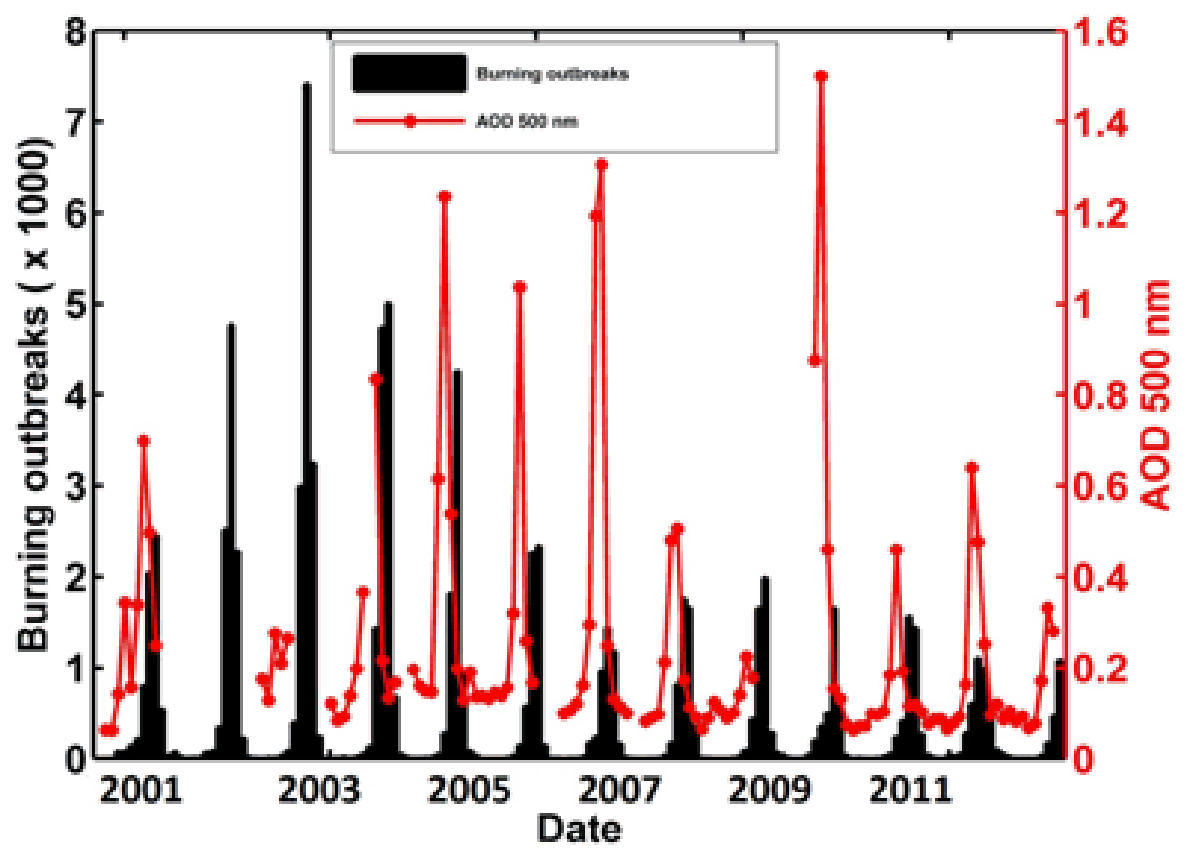

Figure 3. Relationship between the values of AOD $500 \mathrm{~nm}$ and burned records in the state of Mato Grosso

In considering that the fire outbreaks data span a state area coverage level, it realizes that the contribution does not necessarily influence the study area. The study area has Cerrado vegetation characteristic, which it would justify in emissions of material suspended dust because of the great length of exposure to dry. Another fact that must be taken into consideration is the actual particulate emissions by vegetation. Thus, a number of variables must still be analyzed in order to understand the seasonal behavior of AOD $500 \mathrm{~nm}$ values and optical properties for our study area.

The values found for the AOD $500 \mathrm{~nm}$ are daily and monthly in agreement with the vast literature, both the study area studied by [11] and [1] and for areas with the same characteristics as the working [12]developed in the African savanna.

The results obtained clearly observed a seasonal variation of AOD $500 \mathrm{~nm}$ data for the study area. Regarding the maximum and minimum values it can be observed that the methodology proposed in this paper takes a quantitative analysis based on variations of AOD $500 \mathrm{~nm}$ values, it became possible to accompany the annual variations in the data; however, it was revealed the great influence of foci burned in the variations of optical depth values of aerosols.

To assess the possible contributions of fires from other locations, Figure 4 shows the trajectories calculated by HYSPLIT model on the study area. The trajectories were calculated for the years whose AOD $500 \mathrm{~nm}$ values reached the maximum values $(2005,2006,2007$ and 2010) in the critical period of the dry season. It is noted that air movement in the end of September contributes heavily to the increase of the AOD $500 \mathrm{~nm}$. The case records of outbreaks of fire on the southern region of the Amazon rainforest impacted directly the spatial distribution of AOD $500 \mathrm{~nm}$, thus explaining the higher registers of optical depth on the study area.

For 2006 and 2007 dry seasons, the external contributions came mainly from the eastern and northeastern, which are strongly affected by biomass burning that occurs due to cleaning of arable land [13]. Both 2005 and 2010 there has been a great contribution northern study area (Amazon). Deforestation and biomass burning emit large amounts of particulate matter into the atmosphere which directly impacts the area of study.

In general, east, northeast and northern Brazil are the main contributors sources for the increase AOD in Mato Grosso Cerrado so that the maximum are achieved in the dry season, precisely where the fires registration are high in these regions. The local atmospheric motion contributes to transport the particulate matter that impacts the study area. 
NOAA HYSPLIT MODEL

Backward trajectories ending at 1400 UTC 25 Sep 05

GDAS Meteorological Data

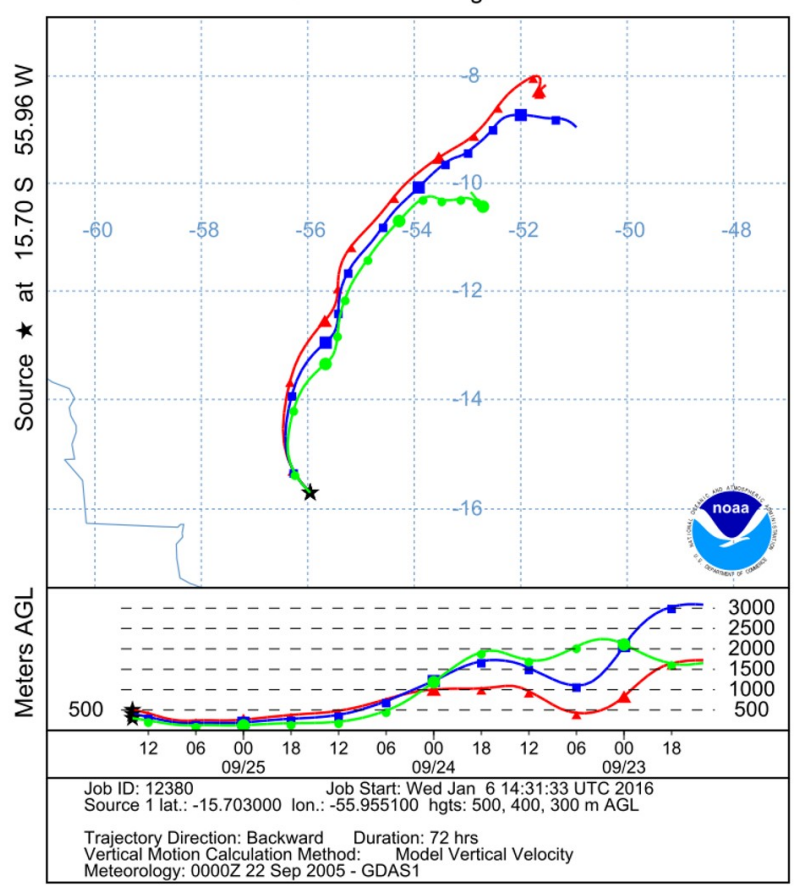

NOAA HYSPLIT MODEL

Backward trajectories ending at 1400 UTC 29 Sep 07

GDAS Meteorological Data

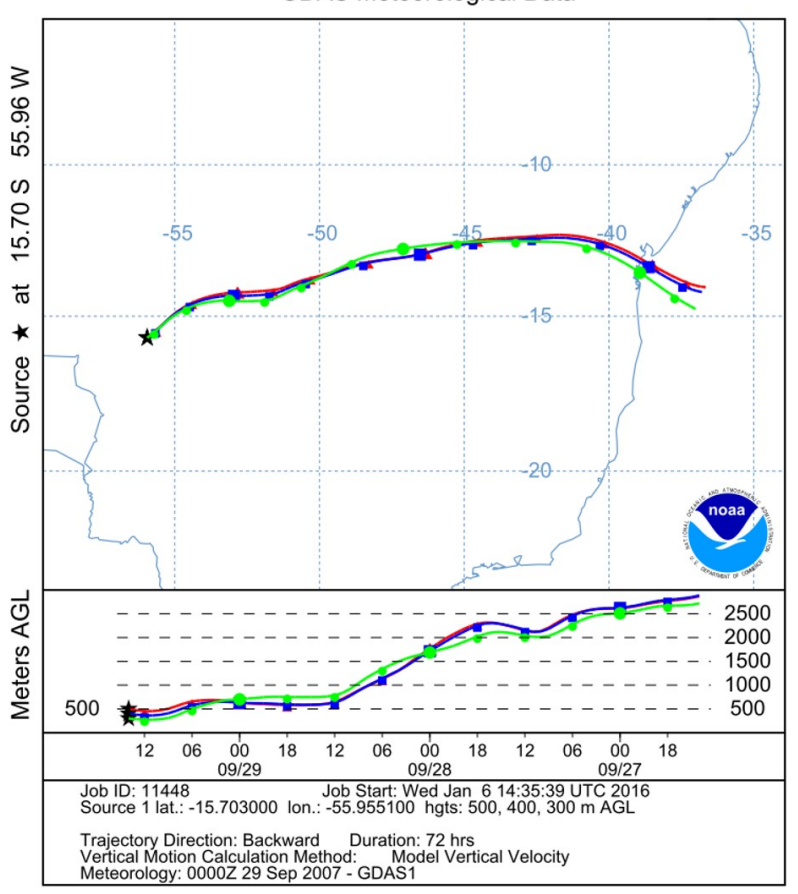

NOAA HYSPLIT MODEL

Backward trajectories ending at 1400 UTC 29 Sep 06 GDAS Meteorological Data

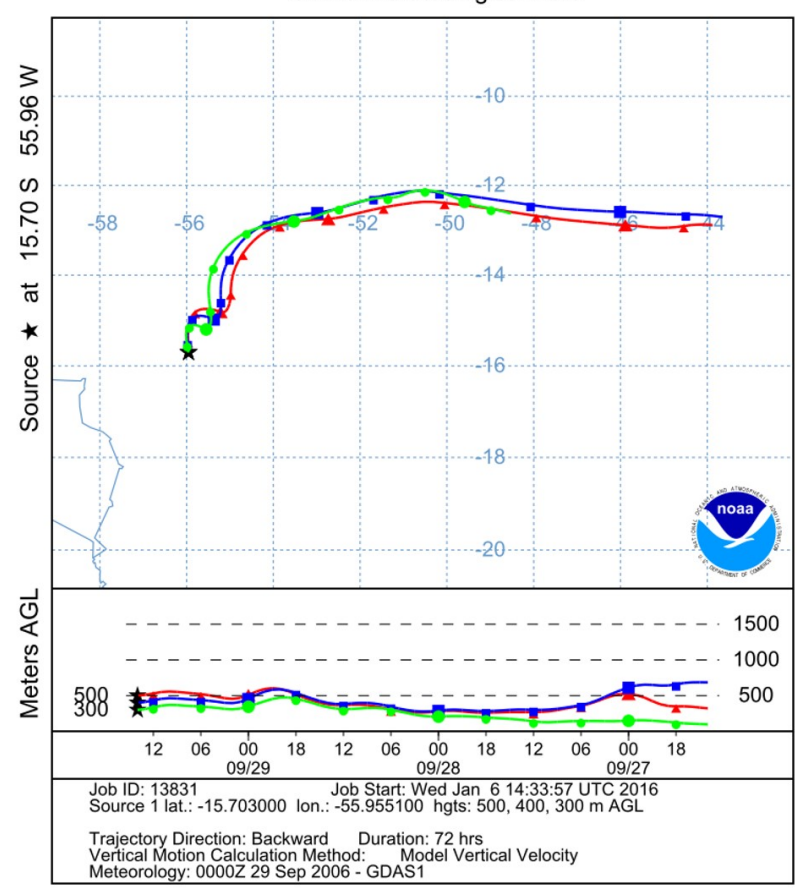

NOAA HYSPLIT MODEL

Backward trajectories ending at 1400 UTC 29 Sep 10 GDAS Meteorological Data

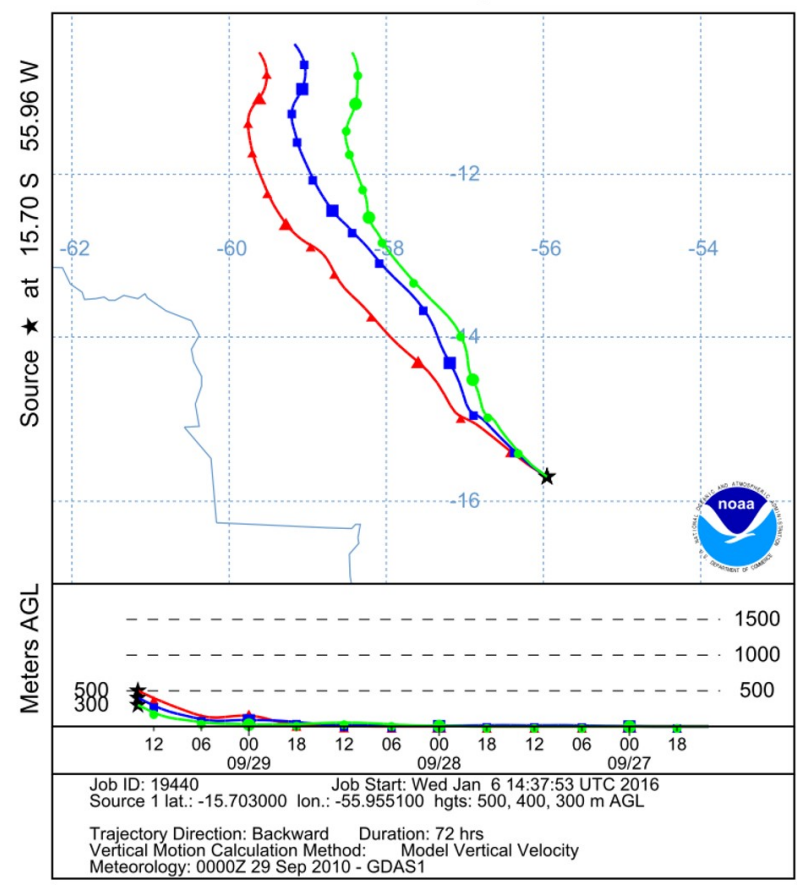

Figure 4. A large figure in one column 


\section{Conclusions}

This study contributes for understanding of the behavior of the optical properties of aerosols in regions with Cerrado characteristics. Daily values of AOD $500 \mathrm{~nm}$ clearly show a seasonal pattern with minimum and maximum in the wet and dry season, respectively. The minimum values were concentrated in about 0,02 in the wet season while the maximum values reached 5, 23 in the dry season. Regarding the inter-annual characterization, it was noticed a non-periodic behavior, with large variations from year to year. The monthly averages of AOD $500 \mathrm{~nm}$ were correlated with the monthly records of outbreaks of fire for the state of Mato Grosso, however there was no statistically significant correlation, which shows that such a relationship exists, but it is not direct. The relationship between monthly values of AOD $500 \mathrm{~nm}$ and fire outbreak records was perceived through the high of AOD values $500 \mathrm{~nm}$ when an increase in values in records of outbreaks of fire. Regarding the maximum and minimum values it can be observed that the methodology proposed in this paper takes a quantitative analysis based on variations of AOD $500 \mathrm{~nm}$ values, it became possible to accompany the annual variations in the data, however it was revealed the great influence of foci burned in the variations of optical depth values of aerosols. The case records of outbreaks of fire on the southern region of the Amazon rainforest impacted directly the spatial distribution of AOD $500 \mathrm{~nm}$, thus explaining the higher registers of optical depth on the study area.

\section{Acknowledgements}

We thank CAPES for the financial support (process $\mathrm{n}^{\circ}$ 01439213127) and the research group of the Graduate Program in Environmental Physics (project of 457824 / 2013-1 approved process in call $\mathrm{n}^{\circ} 68 / 2013$ $\mathrm{MCTI} / \mathrm{CNPq} / \mathrm{FNDCT}-$ Cross action/LBA) and the research group of the Institute of Physics of the University of São Paulo (USP) for the availability of the AERONET network data.

\section{REFERENCES}

[1] Palácios, R.S., Sallo, F.S., Do Prado, M.J., De Musis, C.R., Nogueira, J.S. Análise da profundidade ótica de aerossóis e coeficiente de Angstron no Cerrado Mato-grossense. Revista Brasileira de Climatologia, Vol. 14, p. 173-185, 2014.

[2] Sena, E. T., Artaxo, P., Correia, A. L. Spatial variability of the direct radiative forcing of biomass burning aerosol and the effects of land use change in Amazonia. Atmospheric Chemistry and Physics, Vol. 13, p. 1261-1275, 2013.
[3] Rodrigues, T. R., G. L. Vourlitis, F. D. A. Lobo, R. G. De Oliveira, J. D. S. Nogueira. Seasonal variation in energy balance and canopy conductance for a tropical savanna ecosystem of south central Mato Grosso, Brazil, J. Geophys.Res. Biogeosci., Vol. 119, p. 1-13, 2014.

[4] Batlle-Bayer, L., Batjes, N.H., Bindraban, P.S. Changes in organic carbon stocks upon land use conversion in the Brazilian Cerrado: A review. Agriculture, Ecosystems and Environment, Vol. 137, p. 47-58, 2010.

[5] Schafer, J.S., Eck, T.F., Holben, B.N., Artaxo, P., Duarte, A. F. Characterization of the optical properties of atmospheric aerosols in Amazônia from long-term AERONET monitoring (1993-1995 and 1999-2006). Journal of Geophysical Research, Vol. 113, D04204, p. 1-16, 2008.

[6] Holben, B. N., Eck, T. F., Slutsker, I., Tanré, D., Buis, J. P., Setzer, A., Vermote, E., Reagan, J.A., Kaufman, Y. J., Nakajima, T., Lavenu, F., Jankowiak, I., Smirnov A. AERONET - a federated instrument network and data archive for aerosol characterization. Remote Sensing of the Environment, Vol. 66, n. 1, p. 1-16, 1998.

[7] Smirnov, A., Holben, B. N., Eck, T. F., Dubovik, O., Slutsker, I. Cloud screening and quality control algorithms for the AERONET data base. Remote Sensing of the Environment, Vol.73, p. 337-349, 2000.

[8] INPE, Instituto Nacional de Pesquisas Espaciais. Portal do Monitoramento de Queimadas e Incêndios. Disponível em http://www.inpe.br/queimadas. Acesso em: 29/03/2015.

[9] Draxler, R.R., Rolph, G.D. HYSPLIT (HYbrid Single-Particle Lagrangian Integrated Trajectory) Model Access via the NOAA ARL READY Website. NOAA Air Resources Lab., Silver Spring, Md. Available at: http://www.arl.noaa.gov/ready/hysplit4.html, 2003.

[10] Houghton, J. T., MeiraFilho, L. G., Callander, B. A., Harrris, N., Kattenberg, A., Maskell, K. (Eds) Climate Change 1995: The Science of Climate Change. Cambridge University Press, Cambridge, UK, 1996.

[11] Procopio, A.S., Artaxo, P., Kaufman, Y. J., Remer, L.A., Schafer, J.S., Holben, B. N. Multiyear analysis of Amazonian biomass burning smoke radiative forcing of climate. Geophysical Research Letters, Vol. 31, L03108, p. 1-4, 2004.

[12] Kumar, K. R., Sivakumar, V., Reddy, R.R., Gopal, K. R., Adesina, A. J. Inferring wavelength dependence of AOD and Ångström exponent over a sub-tropical station in South Africa using AERONET data: Influence of meteorology, long-range transport and curvature effect. Science of the Total Environment, Vol. 461-462, p. 397-408, 2013.

[13] Vieira-Filho, M.S., Pedrotti, J. J., Fornaro, A. Contribution of long and mid-range transport on the sodium and potassium concentrations in Rainwater samples, São Paulo megacity, Brazil. Atmospheric Environment, Vol. 79, p. 299-307, 2013.

[14] ROCHA, V. R., and YAMASOE, M. A. Estudo da variabilidade espacial e temporal da profundidade óptica de aerossol obtida com o MODIS sobre a região amazônica.Revista Brasileira de Meteorologia, Vol .28, n.2, p. $210-220,2013$

[15] Revista Brasileira de Meteorologia, Vol.28, n.2, p. 013. 